\title{
AN EMPIRICAL STUDY OF CRITICAL SOFT FACTORS FOR QUALITY IMPROVEMENT IN THE ELECTRICAL AND ELECTRONICS FIRMS IN MALAYSIA
}

\author{
Muhammad Madi Abdullah \\ College of Business Management and Accounting \\ Universiti Tenaga Nasional, Malaysia \\ madi@uniten.edu.my
}

\begin{abstract}
Soft factors are important aspect that sustains the organizations in their efforts towards continuous quality improvement (QI) and customer satisfaction. The conventional wisdom states that quality improvement in organizations increases profits and productivity. Therefore, the aim of the paper is to examine the influence of critical soft factors (CSF) on quality improvement (QI). For that purpose, this study examine: (i) the relationship between the CSF and QI and (ii) to what extent the six CSF explain QI. The study used survey data from 255 electrical and electronics (E\&E) firms in Malaysia. The individual managers representing the each firm made the unit of analysis of the study. The finding reveals that QI was significantly influenced by the following soft factors: management commitment, customer focus, employee involvement, training \& education, and reward \& recognition. Supplier relationship was not a significant predictor of quality improvement. Finally, this study has empirically shown that quality improvement will increase when the organizations emphasize more on soft factors.
\end{abstract}

Keywords: Critical soft factors, quality improvement, Electrical and Electronics firms

\section{INTRODUCTION}

Business organizations all over the world including the Malaysian organizations have to maintain and enhance their competitiveness in the face of fierce global competition, changing markets and technological break through. Also, since the implementation of ASEAN Free Trade Area (AFTA) agreement in 1992, competition has become intense among the ASEAN countries (Zadry and Yusof, 2006). Facing this challenge, manufacturing and service firms should produce high-quality goods and services (Evans and Lindsay, 2002). Therefore, Malaysian organizations would lose ground to competitors if they do not responsive to changes. To compete in this global market, Malaysian manufacturers have long realized that they need to produce quality goods and services (Agus and Abdullah, 2000).

Quality improvement (QI) has been recognized by many firms as a strategy to compete. Higher quality implies lower costs and increased productivity, which in turn gives the firm a greater market share and better competitive levels (Deming, 1982; Evans and Lindsay, 2002). Thus, QI plays an important role towards the productivity and performance of an organization. Therefore, it appears that quality improvement practices are important for continuous survival of Malaysian E\&E organizations. 
Literature has shown that quality improvement has been applied as a way of improving activities and performance either in small or large firms using both factual data (Easton and Jarrell, 1998; Hendricks and Singhal, 2001) and perceptual data (Powell, 1995; Samson and Terziovski, 1999; Kaynak, 2003; Prajogo and Sohal, 2006). Several other empirical researches also supported the proposition that better quality has a positive relationship with firm performance (Flynn et al., 1997; Adam et al. 1997; Heras, 2006; Sharma, 2006).

These kinds of studies are scarce in Electrical and Electronics (E\&E) firms. Most of the previous empirical studies devoted to quality improvement focused on manufacturing firms, service sector or a combination of manufacturing and service firms, while only a few studies that have analyzed quality improvement practice in E\&E organizations (Ismail et al., 1998; Agus, 2001; Eng Eng and Yusof, 2003). Moreover, the quality process and performance among the E\&E sector in Malaysia is still below the level expected to generate the required economic national growth in realizing to be a high tech industrial nation by 2020 (Idris et al., 1996; Best and Rasiah, 2003).

Accordingly, more empirical research may be conducted on the critical soft factors that can truly promote and enhance the successful QI practices in these organizations. In this line, extensive replication seems essential to ensure the reliability and validity of this research. As is known, replications may improve the understanding of the state of different fields and facilitate theory development (Easley et al., 2000; Singh et al., 2003).

The aim of the paper is to examine the influence of critical soft factors (CSF) on quality improvement (QI) in $255 \mathrm{E \& E}$ firms in Malaysia. This approach is developed from the point of view of replication research, and uses regression and correlation analysis to test the relationships between CSF and QI; this would test the generalizability of existing theory. For that purpose, this study examine: (i) the relationship between the CSF and QI and (ii) to what extent the six CSF explain QI. The contribution made by the paper consequently lies in the expansion of the link between soft factors and quality improvement through the complementation of the empirical results about these issues in the scarce literature dedicated to quality improvement in the $\mathrm{E} \& \mathrm{E}$ firms. The paper is organized as follows. Next section reviews the critical soft factors of quality improvement from several literatures and suggests the research framework. Then, it discloses the research methodology section and presents the results of testing the model and the implications to managers. Finally, the paper includes with several conclusions, limitations, and further research.

\section{REVIEW OF THE RELATED LITERATURE}

\section{Critical Soft Factors of Quality Improvement}

Literature has identified the key factors for successful quality improvement implementation. These factors have been provided by contributions from quality lead- 
ers (Deming, 1982; Juran, 1982), formal evaluation models (EQA, MBNQA, Deming Award) and measurement studies (Saraph et al., 1989; Flynn et al., 1994). This theory has identified the quality improvement practices. Table 1 shows the critical factors of quality improvement based on some of the studies which have analyzed the quality measurement instruments. The researches by all these authors show some common issues which can be considered as critical for successful continuous QI efforts. Out of these factors, literature has suggested that they may be classified as soft and hard factors (Wilkinson, 1992; Powell, 1995; Ho et al., 2001; Rahman and Bullock, 2005).

The hard part includes production and work process control techniques, which ensure the correct functioning of such processes (amongst others, process design, the "just in time" philosophy, the ISO 9000 norm and the seven basic quality control tools) (Wilkinson et al., 1998; Evans and Lindsay; 2002). The soft factors are the behavioral aspects of management or the 'human factors', such as leadership, human resource management (HRM), employee involvement and empowerment (Rahman, 2004).

Other scholars have identified the soft factors or group soft factors of quality improvement which have a positive influence on quality improvement (Lu and Sohal, 1993; Shin et al., 1998; Yusof and Aspinwall, 1999; Rahman and Bullock, 2005). Alongside with these studies, there were also some other general studies that carried out specifically in Malaysian context which has also identified the critical soft factors of quality improvement such as leadership, employee training, communication, employee reward and supplier relation (Idris et al., 1996; Agus, 2001; Eng Eng and Yusof, 2003). Besides, the quality improvement models such as Malcolm Baldridge, European Foundation for Quality Management, and the Deming Prize have also identified soft factors such as leadership, process management, training, communication, teamwork, learning as the key aspects for effective quality improvement. These critical soft factors are key to quality improvement because the may have a positive impact on firm performance. 
Table1: Critical Factors of Quality Improvement

\begin{tabular}{|c|c|c|}
\hline \multirow{2}{*}{$\begin{array}{l}\text { Measurement studies } \\
\text { 1. Saraph et al. (1989) }\end{array}$} & \multicolumn{2}{|c|}{ Quality improvement measures } \\
\hline & \multicolumn{2}{|c|}{$\begin{array}{l}\text { Role of divisional top management and quality policy } \\
\text { Role of the quality department } \\
\text { Training } \\
\text { Product/service design } \\
\text { Supplier quality management } \\
\text { Process management } \\
\text { Quality data and reporting } \\
\text { Employee relations }\end{array}$} \\
\hline 2. Flynn et al. (1994) & \multicolumn{2}{|c|}{$\begin{array}{l}\text { Top management support (quality leadership, quality improvement rewards) } \\
\text { Quality information (process control, feedback) } \\
\text { Process management (cleanliness and organization) } \\
\text { Product design (new product quality, inter-functional design process) } \\
\text { Workforce management (selection for teamwork potential, teamwork) } \\
\text { Supplier involvement (supplier relationship) } \\
\text { Customer involvement (customer interaction) }\end{array}$} \\
\hline 3. Ahire et al. (1996) & $\begin{array}{l}\text { Top management commitment } \\
\text { Customer focus } \\
\text { Supplier quality management } \\
\text { Design quality management } \\
\text { Benchmarking } \\
\text { SPC usage } \\
\text { Internal quality information usa } \\
\text { Employee empowerment } \\
\text { Employee involvement } \\
\text { Employee training } \\
\text { Product quality } \\
\text { Supplier performance }\end{array}$ & \\
\hline $\begin{array}{l}\text { 4. Grandzol and Gershon } \\
\text { (1998) }\end{array}$ & $\begin{array}{l}\text { Leadership } \\
\text { Continuous improvement } \\
\text { Employee fulfilment } \\
\text { Learning } \\
\text { Process management } \\
\text { Internal/external cooperation } \\
\text { Customer focus }\end{array}$ & \\
\hline 5. Quazi and Padibjo (1998) & $\begin{array}{l}\text { Leadership } \\
\text { Information and analysis } \\
\text { Strategic planning } \\
\text { Human resource utilization } \\
\end{array}$ & $\begin{array}{l}\text { Quality results } \\
\text { Customer satisfaction } \\
\text { Management of process quality }\end{array}$ \\
\hline 6. Rao et al. (1999) & $\begin{array}{l}\text { Top management support } \\
\text { Strategic quality planning } \\
\text { Quality information availability } \\
\text { Quality information usage } \\
\text { Employee training } \\
\text { Employee involvement } \\
\text { Product/process design }\end{array}$ & $\begin{array}{l}\text { Supplier quality } \\
\text { Customer orientation } \\
\text { Quality citizenship } \\
\text { Benchmarking }\end{array}$ \\
\hline 7. Conca et al. (2004) & $\begin{array}{l}\text { Leadership } \\
\text { Quality planning } \\
\text { Employee management } \\
\text { Supplier management }\end{array}$ & $\begin{array}{l}\text { Process management } \\
\text { Continuous improvement } \\
\text { Learning } \\
\text { Customer focus }\end{array}$ \\
\hline
\end{tabular}

Note: The researchers' ideas were summarized for this study 


\section{Research Framework}

Thus, by incorporating the theoretical ideas and discussions earlier, this study develops a new structural framework that incorporates the importance of the six CSF for organizational QI.

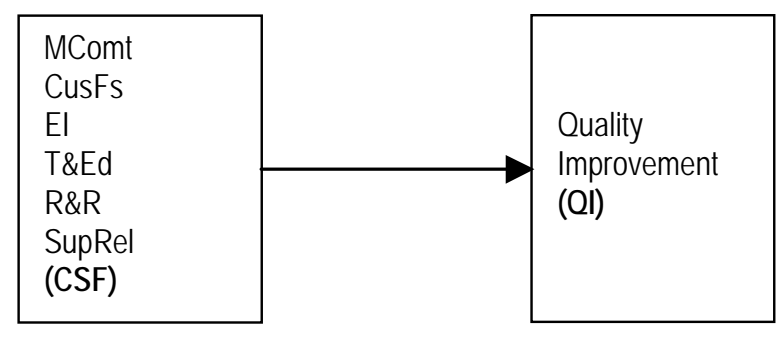

IVs

DV

Figure 1: Research Framework

The basic idea of the conceptual framework is to find out whether the critical soft factors will lead the organizations to achieve for higher QI. Figure 1 above presents the conceptual framework of the present study relating critical soft factors and quality improvement. The figure depicts the research framework containing six independent variables (IVs) comprising of six critical soft factors (CSF) and dependent variable (DV), quality improvement (QI). The independent variables are listed on the far left of the figure and the dependent variable is on the right. The independent variables are (1) management commitment (MComt), (2) customer focus (CusFs), (3) employee involvement (EI), (4) training and education (T\&Ed), (5) reward and recognition (R\&R) and (6) supplier relationship (SupRel) and the dependent variable is quality improvement (QI).

\section{RESEARCH METHODOLOGY}

\section{Population and Sample}

The target population of this study is made up of $676 \mathrm{E \& E}$ firms from West Malaysia. The sample firms were drawn through simple random sampling from the list obtained from the Federal Malaysian Manufacturers (FMM) (FMM-MATRADE, 2003). 550 structured questionnaires with closed questions were mailed to the selected firms. Firstly, a pre-test was carried out with 15 firms. This pre-test helped to improve the structure and content of the questionnaire. Finally, the research is based on data from 255 respondents and this made the final sample. The questionnaire was answered by the persons in charge of the quality area in E\&E firm. 


\section{Measurements}

Some scales were developed to measure CSF and QI after reviewing the conceptual and empirical literature. Perceptual variables were used and perceptual constructs were tested empirically for reliability. Each was assessed on a ten-point Likert's scale continuum. Firstly, for measuring the six CSF, the researcher has used the original questionnaire developed and empirically validated by Zhang (2000). Secondly, to measure the overall quality improvement practices (QI) construct, the researcher has used the instrument developed and also empirically validated by Flynn et al. (1994). This questionnaire contains information on both, the soft part of quality improvement practices (soft quality practices) and as well as the hard aspects (hard quality practices) which make up the overall quality improvement in the organizations. Cronbach Alphas in our study was 0.96 and 0.90 for overall CSF and overall QI.

\section{Analytic Methods}

Statistical techniques such as correlations, and regression analysis deemed appropriate and suitable for analyzing the relationships in the study were considered. The statistics employed were determined to a great extent by the designs of the study and also the types of measurement scale characterizing the dependent variables. All the inferential statistics used in the study were evaluated using the onetailed test. The significance level or probability level ( $p$-value) of 0.05 was used as the standard acceptable level.

\section{FINDINGS AND DISCUSSION}

\section{Descriptive and Correlation Analysis}

Table 2 provides the descriptive analysis for all the variables that incorporated in the study. Based on the ten-point scale used, the overall mean QI rating was 6.41 implying that the overall level of QI was fairly good in the sample firms. The findings in Table 2 also indicated that the mean ratings for the independent variables in descending order of high to low were management commitment (8.25), customer focus (7.05), training and education (6.97), reward and recognition (6.72), employee involvement (6.37) and supplier relationship (6.28).

Table2: Descriptive Statistics and Pearson Correlations between CSF and QI

\begin{tabular}{lllcccccc}
\hline Variables & Mean & SD & 1 & 2 & 3 & 4 & 5 & 6 \\
\hline 1.QI & 6.41 & 0.89 & & & & & & \\
2.MComt & 8.25 & 0.79 & $\mathbf{0 . 2 8 1}$ & & & & & \\
3.CusFs & 7.05 & 1.14 & $\mathbf{0 . 3 9 1}$ & $\mathbf{0 . 5 4 2}$ & & & & \\
4.El & 6.37 & 1.04 & $\mathbf{0 . 2 3 7}$ & $\mathbf{0 . 5 5 9}$ & $\mathbf{0 . 5 1 1}$ & & & \\
5.T\&Ed & 6.97 & 1.03 & $\mathbf{0 . 1 1 2}$ & $\mathbf{0 . 4 1 9}$ & $\mathbf{0 . 5 6 9}$ & $\mathbf{0 . 6 7 7}$ & & \\
6.R\&R & 6.72 & 1.32 & $\mathbf{0 . 3 1 6}$ & $\mathbf{0 . 3 6 4}$ & $\mathbf{0 . 4 2 9}$ & $\mathbf{0 . 5 6 8}$ & $\mathbf{0 . 4 2 9}$ & \\
7.SupRe & 6.28 & 1.02 & $\mathbf{0 . 1 9 1}$ & $\mathbf{0 . 5 3 7}$ & $\mathbf{0 . 5 3 7}$ & $\mathbf{0 . 4 9 2}$ & $\mathbf{0 . 4 0 2}$ & $\mathbf{0 . 5 0 2}$ \\
\hline
\end{tabular}

Notes: Zero-order coefficients $p<0.05$, Benforroni adjusted alpha $=0.008(0.05 / 6)$ 
Table 2 also shows that all the six CSF (six independent variables) were significantly positively associated with the dependent variables (QI and OP) (see figures in bold). These results showed that the six CSF have a positive correlation with QI practice. Therefore, the six CSF may impact on quality improvement. In this sense, organizational QI will increase when the firms emphasize more on the six CSF.

\section{The Relationship between Critical Soft Factors and Quality Improvement}

To find out the best set of predictors of QI, a-six predictors multiple linear regression model was proposed. The six-predictor variables are management commitment $\left(X_{1}\right)$, customer focus $\left(X_{2}\right)$, employee involvement $\left(X_{3}\right)$, training and education $\left(X_{4}\right)$, reward and recognition $\left(X_{5}\right)$, and supplier relationship $\left(X_{6}\right)$. The equation of the proposed multiple linear regression model is as follows:

$Y(Q I)=b_{0}+b_{1}\left(X_{1}\right)+b_{2}\left(X_{2}\right)+b_{3}\left(X_{3}\right)+b_{4}\left(X_{4}\right)+b_{5}\left(X_{5}\right)+b_{6}\left(X_{6}\right)+e$

Where: $b_{0}=$ Constant,$e=$ Error

To determine the best set of predictor variable in predicting QI, a stepwise regression method was used. Based on the stepwise method used, only five predictor variables were found to be of significance in explaining QI. They are management commitment $\left(X_{1}\right)$, customer focus $\left(X_{2}\right)$, employee involvement $\left(X_{3}\right)$, training and education $\left(X_{4}\right)$ and reward and recognition $\left(X_{5}\right)$. Supplier relationship $\left(X_{6}\right)$ was excluded because it did not contribute in significance $(t=0.367, p=0.714)$ to the variation of the dependent variable (QI).

Table 3: Estimates of coefficients for the model

\begin{tabular}{lccccc}
\hline \multicolumn{1}{c}{ CSF } & $\begin{array}{c}\text { B } \\
\text { (Unstandardized } \\
\text { Coefficients) }\end{array}$ & $\begin{array}{c}\text { Std. } \\
\text { error }\end{array}$ & $\begin{array}{c}\text { Beta (Standarized } \\
\text { coefficients) }\end{array}$ & $\mathrm{t}$ & $\mathrm{p}$-value \\
\hline Constant & 1.992 & 0.152 & & 13.136 & 0.0001 \\
Mcomt $\left(\mathrm{X}_{1}\right)$ & 0.160 & 0.026 & 0.141 & 6.109 & 0.0001 \\
CusFs $\left(\mathrm{X}_{2}\right)$ & 0.152 & 0.035 & 0.193 & 4.353 & 0.0001 \\
El $\left(\mathrm{X}_{3}\right)$ & 0.479 & 0.037 & 0.556 & 13.058 & 0.0001 \\
T\&Ed $\left(\mathrm{X}_{4}\right)$ & 0.056 & 0.028 & 0.064 & 2.021 & 0.0440 \\
R\&R $\left(\mathrm{X}_{5}\right)$ & 0.200 & 0.021 & 0.294 & 9.668 & 0.0001 \\
\hline
\end{tabular}

$R=0.968 ; R^{2}=0.938 ;$ Adj. $R^{2}=0.936$

As depicted in the Table 3, the estimated model is as below:

$Y(Q I)=1.992+0.160\left(X_{1}\right)+0.152\left(X_{2}\right)+0.479\left(X_{3}\right)+0.056\left(X_{4}\right)+0.200\left(X_{5}\right)+e$

The R-squared of 0.938 implies that the five predictor variables explain about $93.8 \%$ of the variance/variation in the QI. This is a very good and respectable result. The ANOVA table revealed that the F-statistics (748.342) is extremely large 
and the corresponding $p$-value is highly significant $(0.0001)$ or lower than the alpha value of 0.05 . This indicates that the five-predictor variables have a significant impact on QI. However, supplier relationship is not a significant predictor in explaining QI. This is because this variable was considered as least important as supported by the studies of Eng Eng and Yusof (2003) in Malaysian E\&E firms, and Yusof and Aspinwall (1999) in UK companies who found that most of the small sized firms adopted very low level of supplier relationship in which this factor is having a trivial/very small effect to QI.

Table 3 shows the largest beta coefficient $(0.479)$ for employee involvement. This means that this variable makes the strongest unique contribution to explaining the dependent variable (QI), when the variance explained by all other predictor variables in the model is controlled for. It suggests that one standard deviation increase in employee involvement is followed by 0.479 standard deviation increase in QI. The Beta value for reward and recognition is the second highest, followed by management commitment. In the fourth place are customer focus and training and education is in the fifth place. This finding supports the studies of Bullington et al. (2002), AlOmaim et al. (2003), Baidoun (2003), and Baidoun and Zairi (2003).

\section{Implication for Managers}

The results suggested that CSF such as management commitment, customer focus, employee involvement, training and education, reward and recognition and supplier relationship are significantly positively associated with overall QI. This implies to the managers that by focusing and implementing the six critical soft factors in E\&E firms, it would promote overall QI in the firms. Thus, the managers should understand that effective implementation of the CSF will lead to greater quality improvement.

This study shows that strong and committed leadership in an organization is essential for the successful and enduring quality programs. Therefore the firm managers should play an important role in the entire firm's QI implementation. In terms of customer, firm managers must also take the initiative to make adjustments to improve continuously the quality of their products, which is necessary for increasing self-confidence and pride of the workforce in serving the customers. In order to achieve this, the managers have to increase awareness-their own as well as all employees'-of the changing needs of customer demands and markets, as well as heightened worldwide competition for better quality products.

In relation to employee involvement, firm managers should realize that to empower employees and to develop an appropriate culture for continuous QI requires training the employees to improve their interactive skills (such as communication, effective meeting, empowerment and leadership skills), and training in problem identification and solving skills, quality improvement skills, and other technical skills. Managers must also ensure that employees in the organization should be continually developed and given adequate training and education on prescriptions, methods and 
the concept of quality that usually included quality improvement principles, team skills, communication skills and problem solving skills. In this sense, the firm must provide the employees with continuous training and education in work related and statistical techniques so that problem identification and problem solving abilities of them at all levels are enhanced and improved continuously. In terms of reward and recognition, the managers must realize that employees in organization are more likely to share their ideas for work improvements when managers give them credit and recognition for their contributions to the organizations. Employee recognition programs can enhance effective employee relations by communicating to all employees that the organization cares about their ideas and is willing to reward them for their initiatives and efforts.

\section{CONCLUSIONS}

The research proposed here reflects the empirical results showing the relationship between CSF and QI. This paper has used the answers from $255 \mathrm{E} \& \mathrm{E}$ firms in Malaysia in order to carry out a replication. Building on previous studies in this area, this paper presents new results evidencing the importance of this relationship in a different sample. In this sense, several authors have recognized that conducting replication studies is crucial to the development and growth of scientific knowledge within a given discipline. The contribution to the discipline of quality management by this study is showing that the link between CSF and QI may be generalizable. Five of the six CSF in this study have shown to have a very high positive significant influence on QI practice. The implication is that managers need to focus more on the CSF to achieve for higher QI.

The significant of this study is one can learn more about the CSF for effective QI implementation in Malaysian firms and also for global managers. Based on these ideas, managers can prepare themselves, their employees, and their organizations for the consequences of changes, to the benefits of all stakeholders in the organization. The managers by using the proposed framework would be able to gauge the amount of variances in quality improvement which can be accounted by the identified determinants (CSF) which are the independent variables in the study. It can then serve as a guide for the organizations to take the necessary steps to improve the current management practices by concentrating more on the factors which will facilitate and enhance QI.

The data collected from the study will also empirically show the relationships between the constructs incorporated in the study in an attempt to generate a better and sound theoretical framework within which to understand more about the relationship between the CSF and QI.

Finally, this study is subject to some limitations: (1) the cross-sectional nature of the data, (2) the sample in the study included only the private E\&E organizations in West Malaysia, and (3) several CSF may have been not considered. Given 
these limitations, further research might be carried out in three directions. First, a longitudinal research would complement this work to support these relationships on a longitudinal basis. Second, other member countries in ASEAN such as Singapore, Thailand, Brunei and Thailand could be included in order to make comparisons in terms of QI practices. Also, it may be replicated in the public sector which would provide further validation and reinforcement to the model proposed in this study. Third, future studies could look into the possible inclusion of few other soft factors such as communication (Black and Porter, 1995), quality culture (Ahire et al., 1996) and teamwork (Yusof and Aspinwall, 1999) in relation to QI.

\section{REFERENCES}

Adam, E.E., Corbett, L.M., Flores, B.E., Harisson, N.J., Lee, T.S., Rho, B.H., Ribera, J., Samson, D., \& Westbrook, R. (1997). An international study of quality improvement and firm performance, International Journal of Operations \& Production Management, 17, 842-873.

Agus, A., \& Abdullah, M. (2000). Total quality management practices in manufacturing companies in Malaysia: An exploratory analysis, Total Quality Management, 8, 1041-1051.

Agus, A. (2001). The structural linkages between TQM, product quality performance, and business performance: Preliminary empirical study in Electronics companies, Singapore Management Review, 27, 87-105.

Ahire, S.L., Golhar, D.Y., \& Waller, M.A. (1996). Development and validation of TQM implementation constructs, Decision Sciences, 27, 23-56.

Al-Omaim., N, Zairi, M., \& Ahmed, A.M. (2003). Generic framework for TQM implementation within Saudi context: An empirical study, Working paper series, School of Management, University of Bradford, UK.

Baidoun S. (2003). An empirical study of critical factors of TQM in Palestinian organizations, Logistics Information Management, 16,156-171.

Baidoun, S., \& Zairi, M. (2003). A proposed model of TQM implementation in the Palestinian context, Total Quality Management and Business Excellence, 14, 1193-1211.

Best, M.H., \& Rasiah, R. (2003). Malaysian Electronics: At the crossroads. United Nations Industrial development Organization (UNIDO), Vienna.

Black, S., \& Porter, L.J. (1995). An empirical model for quality management, Total Quality Management, 6, 149-164. 
Bullington, S.F., Easley, J.Y., Greenwood, A.G., \& Bullington, K.E. (2002). Success factors in initiating versus maintaining a quality improvement process, Engineering Management Journal, 14, 8-14.

Conca, F.J., Llopis, J., \& Tarí, J.J. (2004). Development of a measure to assess quality management in certified firms, European Journal of Operational Research, 156, 683-697.

Deming, W.E. (1982). Quality, productivity and competitive position (Cambridge, MA, USA: MIT center for advanced engineering study).

Easley, R.W., Madden, C.S., \& Dunn, M.G. (2000). Conducting marketing science: The role of replication in the research process, Journal of Business Research, 48, 83-92.

Easton, G.S., \& Jarrell, S.L. (1998). The effects of total quality management on corporate performance: An empirical investigation, Journal of Business, 71, 253-307.

Eng Eng, Q., \& Yusof, S.M. (2003). A survey of TQM practices in the Malaysian electrical and electronics industry, Total Quality Management \& Business Excellence, 14, 63-67.

Evans, J.R., \& Lindsay, W.M. (2002). The Management and Control of Quality, 5th ed. (USA: South Western, Madison Road).

Flynn, B.B., Schroeder, R.G., \& Sakakibara, S. (1994). A framework for quality management research and an associated measurement instrument, Journal of Operations Management, 11, 339-366.

Flynn, B.B., Schroeder, R.G., Flynn, E.J., Sakakibara, S., \& Bates, K.A. (1997). World-class manufacturing project: Overview and selected results, International Journal of Operations \& Production Management, 17, 671-685.

FMM-MATRADE (2003). Directory . Electrical \& Electronics. 2nd ed. 2003/04. FMM and MATRADE. Malaysia.

Grandzol, J.R., \& Gershon, M. (1998). A survey instrument for standardizing TQM modeling research, International Journal of Quality Science, 3, 80-105.

Hendricks, K.B., \& Singhal, V.R. (2001). Firm characteristics, total quality management, and financial performance, Journal of Operations Management, 19, 269-285.

Heras, I. (2006). How quality management models influence company results- conclusions of an empirical study based on the Delphi method, Total Quality Management \& Business Excellence, 17, 775-794. 
Ho, D.C.K., Duffy, V.G., \& Shih, H.M. (2001). Total quality management: an empirical test for mediation effect, International Journal of Production Research, 39, 529-548.

Idris, M.A., McEwan, W., \& Belavendram, N. (1996). The adoption of ISO and total quality management in Malaysia, The TQM Magazine, 8, 65-68.

Ismail, M.Y., Baradie, M.E.I., \& Hashmi, M.S.J. (1998). Quality management in the manufacturing industry: Practice Vs Performance, Computers \& Industrial Enggineering, 35, 519-522.

Juran, J. (1982). Juran on quality improvement (New York, NY: Juran Institute).

Kaynak, H. (2003). The relationship between TQM practices and their effects on firm performance, Journal of Operations Management, 21, 405-435.

Lu, E., \& Sohal, A. (1993). Success factors, weaknesses and myths concerning TQM implementation in Australia, Total Quality Management, 4, 245-255.

Powell, T.C. (1995). Total quality management as competitive advantage: a review and empirical study, Strategic Management Journal, 16, 15-37.

Prajogo, D.I., \& Sohal, A.S. (2006). The relationship between organization strategy, total quality management (TQM) and organization performance-the mediating role of TQM, European Journal of Operational Research, 168, 35-50.

Quazi, H.A., \& Padibjo, S.R. (1998). A journey toward total quality management through ISO certification: A study on small and medium sized enterprises in Singapore, International Journal of Quality and Reliability Management, 15, 489-508.

Rahman, S. (2004). The future of TQM is past. Can TQM be resurrected? Total Quality Management, 15, 411-422.

Rahman, S., \& Bullock, P. (2005). Soft TQM, hard TQM, and organizational performance relationships: an empirical investigation, Omega, 33, 73-83.

Rao, S.S., Solis, L.E., \& Ragunathan, T. (1999). A framework for international quality management research: development and validation of a measurement instrument, Total Quality Management, 10, 1047-1075.

Samson, D., \& Terziovski, M. (1999). The relationship between total quality management practices and operational performance, Journal of Operations Management, 17, 393-409.

Saraph, J.V., Benson., P.G., \& Schroeder RG. (1989). An instrument for measuring the critical factors of quality management, Decision Sciences, 20, 810-829. 
Sharma, B. (2006). Quality management dimensions, contextual factors and performance: an empirical investigation, Total Quality Management \& Business Excellence, 17, 1231-1244.

Shin, D., Kalinsowski, J.G., \& El-Enein, G.A. (1998). Critical implementation issues in total quality management, SAM advanced Management Journal, 63, 10-14.

Singh, K., Ang, S.H., \& Leong, S.M. (2003). Increasing replication for knowledge accumulation in strategy research, Journal of Management, 29, 533-549.

Wilkinson, A. (1992). The other side of quality: 'soft' issues and the human resource dimension. Total Quality Management, 3, 323-329.

Wilkinson, A., Redman, T., Snape, E., \& Marchington, M. (1998). Managing with total quality management: theory and practice (London: MacMillan).

Yusof, S., \& Aspinwall. E. (1999). Critical success factors for total quality management in small and medium enterprises, Total Quality Management, 10, 803809.

Zadry, H.R., \& Yusof, S.M. (2006). Total quality management and theory of constraints implementation in Malaysian automotive suppliers: a survey result, Total Quality Management \& Business Excellence, 17, 999-1020.

Zhang, Z.H. (2000). Developing a model of quality management methods and evaluation their effects on business performance. Total Quality Management, 11, 129-137. 